\title{
PELATIHAN PENGUATAN KELEMBAGAAN EKONOMI MASYARAKAT MELALUI ARISAN SAPI DI DESA SAWERIGADI KECAMATAN BARANGKA KABUPATEN MUNA BARAT
}

\author{
La Bilu ${ }^{1}$, Salimin A $^{2}$, Hamuni ${ }^{3}$, Syahbudin ${ }^{4}$, Nerlin $^{5}$ \\ ${ }^{1}$ Jurusan PPKn-FKIP-Universitas Halu Oleo Kendari \\ email: labilu2012@yahoo.co.id \\ 2Jurusan PPKn-FKIP-Universitas Halu Oleo Kendari \\ email: saliminafamery@yahoo.co.id \\ ${ }^{3} J u r u s a n$ PPKn-FKIP-Universitas Halu Oleo Kendari \\ email: hamuni_farid@yahoo.co.id \\ 4Jurusan PPKn-FKIP-Universitas Halu Oleo Kendari \\ email: syahbuddinbudin@yahoo.co.id \\ ${ }^{5}$ Jurusan PPKn-FKIP-Universitas Halu Oleo Kendari \\ email: nerlinpajak@gmail.com
}

\begin{abstract}
ABSTRAK
Kegiatan pengabdian kepada masyarakat ini dilakukan dengan memberikan pelatihan tentang penguatan kelembagaan ekonomi masyarakat melalui arisan di Desa Sawerigadi Kecamatan Barangka Kabupaten Muna Barat. Arisan sebagai modal sosial merupakan spirit atau kekuatan terwujudnya demokrasi ekonomi pada tataran akar rumput.Tujuannya adalah untuk membuka partisipasi dan keikutsertaan masyarakat secara langsung dalam pengentasan kemiskinan.Sehubungan dengan itu maka urgensi pelatihan ini adalah: (1) Meletakkan masyarakat sebagai penggerak pembangunan di tingkat desa dengan menggunakan modal yang mereka miliki sendiri.(2) mengoptimalkan penggalian potensi sumber daya alam dan sumber daya manusia yang ada di desa, (3 Membangun jaringan bersama antara masyarakat sebagai tempat berdiskusi, tukar pengalaman dan pengetahuan.Khalayak sasaran pengabdian ini adalah kelompok masyarakat marginal miskin yang bermukim di desa Sawerigadi Kecamatan Barangka Kabupaten Muna Barat. Khalayak sasaran terdiri dari 2 kelompok yang berjumlah 50 orang. Masing-masing kelompok yang dibina adalah 25 orang dan berprofesi sebagai petani. Kegiatan pendidikan dan pelatihan ini berjalan dengan lancar dan berhasil. Pelatihan ini menghasilkan soft skill berupa pengetahuan dalam membangun ekonomi kerakyatan yang berbasis pemberdayaan dan hard skill berupa keterampilan dalam memelihara sapi sekaligus sebagai objek arisan.Hal ini dapat ditunjukan dengan indikator keberhasilan evaluasi pelaksanaan pelatihan yakni 76 orang atau (61\%) menunjukkan rentang nilai 86-100 dengan kategori baik sekali, 39 \% dengan kategori baik.
\end{abstract}

\section{PENDAHULUAN}

Modal sosial menjadi isu yang hangat dalam Konferensi Tingkat Tinggi Pembangunan Sosial yang telah dilaksanakan di Kopenhagen 12 Maret 1995. Melalui konferensi ini, modal sosial menjadi kata kunci dalam 
menanggapi tiga agenda pokok pertemuan: mengurangi kemiskinan, menciptakan angkatan kerja yang produktif, dan meningkatkan integrasi sosial. Jenis modal ini luput dari pertimbangan penyelenggara pemerintahan yang umumnya terkesima bahkan terhanyut dalam ritus ideologisasi atas apa yang mereka percayai sebagai pembangunan (Inayah, 2012). Di Indonesia, modal sosial kurang mendapat perhatian padahal ini dapat menjadi suatu kekuatan pembangunan dan pemberdayaan masyarakat. Modal sosial syarat akan nilai yang dapat mendukung percepatan pembangunan. Pasalnya modal sosial memberikan pencerahan tentang makna kepercayaan, kebersamaan, toleransi dan partisipasi sebagai pilar penting pembangunan masyarakat sekaligus pilar bagi demokrasi dan good governance (tata pemerintahan yang baik) yang sedang marak dipromosikan. Sehubungan dengan hal itu, salah satu wujud modal sosial yang menjadi fokus kegiatan pengabdian ini adalah arisan. Arisan merupakan lembaga sosial nonformal yang berasal dan diinisiasi secara otonom oleh masyarakat. Inisiasi tersebut dilatarbelakangi oleh berbagai kepentingan, antara lain: kepentingan ekonomi masyarakat sekitar, sosialisasi, dan silaturahmi.

Hasil wawancara penulis dengan La Ode Faada selaku Kepala Desa Sawerigadi bahwa kegiatan arisan di desanya sudah lama dikenal dan dilakukan. Manfaat arisan tampak dirasakan seperti adanya kebersamaan, dan silaturahmi. Jenis-jenis barang yang menjadi obyek dalam arisan adalah sarung, lemari, barang pecah belah (piring dan gelas) dan adapula dalam bentuk uang tetapi pemanfaatannya kurang terorganisir. Tergantung pada kesepakatan dan kemampuan anggota serta proses pengundiannya sekali dalam satu bulan (wawancara, 12 April 2015).

Arisan yang dilakukan masyarakat ini tidak ada yang salah hanya masih kurang mendukung pemberdayaaan ekonomi masyarakat. Sehubungan dengan itu, maka pengabdian ini menawarkan program arisan yang berbasis pemberdayaan. Artinya peserta arisan diarahkan pada upaya pengentasan kemiskinan. Di mana setiap anggota yang dapat arisan pada prinsipnya muncul kekuatan ekonomi baru atau pelaku ekonomi baru. Oleh karena itu, kegiatan arisan adalah produktif bukan bersifat konsumtif. Jenis arisan yang ditawarkan adalah arisan Sapi.Arisan ini disesuaikan dengan potensi sumber daya lahan yang ada. Sehingga arisan dapat memberikan kontribusi dan menjadi pilar dalam membangun perekonomian masyarakat.

Pelatihan ini memiliki prospek untuk membawa perubahan dalam masyarakat. Arisan sebagai modal sosial dapat menjadi kekuatan dalam mengentaskan kemiskinan. Hal ini diperkuat dengan karya-karya yang berhasil kami rangkum. Bambang Rustanto dalam jurnal Pusat Penelitian dan Pengembangan Kesejahteraan Sosial Kementrian Sosial Republik Indonesia Vol. 12 No. 03 tahun 2007 terungkap bahwa penguatan modal 
sosial yang tumbuh dan berkembang dalam bentuk kelompok sosial, merupakan salah satu pendekatan yang perlu dikembangkan dalam pengentasan kemiskinan. Berdasarkan pengalaman dari Negara-negara berkembang, pendekatan ini dinilai efektif, karena mampu memberdayakan rumah tangga miskin, baik dalam aspek ekonomi, sosial, budaya dan politik. Di dalam pendekatan ini, individu-individu sebagai anggota kelompok mengalami proses belajar sosial, bagaimana mengembangkan potensi dan sumber daya yang dimiliki. Selain itu, melalui pendekatan ini, setiap individu akan terlibat belajar mengembangkan perilaku pro sosial secara efektif guna mengatasi masalah maupun memenuhi kebutuhannya.

Khusnul Ashar dalam jurnal IImu-IImu Sosial (Sosial Science) Volume 21 Nomor 1 Pebruari 2009, hasil penelitiannya menunjukkan bahwa peranan lembaga lokal formal seperti Koperasi dan Bank relatif kecil. Justru modal sosial yang dipupukmelalui kelembagaan Arisan dan Perkumpulan sosial-keagamaan menjadi andalan keluarga kurang mampu di daerah penelitiannya. Pembentukan LKA+ mempunyai prospek yang baik bagi peningkatan kapasitas produktif dan sosial bagi anggotanya. Dengan menambahkan fungsi peningkatan kualitas sumberdaya manusia dalam bentuk pelatihan pada kelembagaan arisan tradisional menunjukkan adanya manfaat yang nyata bagi anggota selama penentuan materi pelatihan dan metodenya disesuaikan dengan karakteristik kegiatan ekonomi pesertanya.

Primadona dalam jurnal Polibisnis, Volume 4 No. 1 April 2012, mengungkapkan bahwa tingginya partisipasi kelompok tani dan adanya kepercayaan diantara anggota kelompok, menjadikan modal sosial sebagai instrumen pemberdayaan masyarakat menunjukkan keberhasilannya. Para petani dapat menjalankan bisnisnya dengan baik melalui jaringan modal sosial.

Hasil penelitian Oman Sukmana dalam Jurnal Humanity, Volume 1 Nomor 1 September 2005, menunjukkan bahwa keberadaan institusi sosial dan modal sosial di desa Sukomulyo, kecamatan Pujon telah berdampak positif pada upaya meningkatkan dan pemberdayaan masyarakat miskin di pedesaan. Dampak positif tersebut dirasakan, baik dari aspek ekonomi, sosial, budaya, politik dan agama.

Tri Panadji dalam Jurnal Agro Ekonomi Volume 2 Oktober 2006 dalam penelitiannya menunjukka bahwa pada masyarakat desa yang memiliki modal sosial yang relatif kuat maka tingkat kesejahteraannya cenderung lebih tinggi dan proses transformasi sosial ekonomi lebih cepat. Program pemberdayaan masyarakat pedesaan dalam pengelolaan Agroeokostem Lahan Kering selama ini masih menekankan pada pemberian bantuan material dan kurang pada penguatan modal sosial setempat.

Muliyadi dalam jurnal Sosiokonsepsia Volume 17 Nomor 02 Tahun 2012, dalam penelitiannya menunjukkan bahwa petani pinggiran kota 
melalui sentuhan kebersamaan masyarakat lainnya memperoleh manfaat berupa diperolehnya pemenuhan kebutuhan fisik minimum bagi keluarganya dan pendidikan anak. Bahkan sementara petani dapat menabung dan meningkatkan kesejahteraan keluarganya.

Secara umum modal sosial adalah merupakan hubungan-hubungan yang tercipta dan norma-normayang membentuk kualitas dan kuantitas hubungan sosial dalam masyarakat dalam spectrum yang luas, yaitu sebagai perekat sosial (sosial glue) yang menjaga kesatuan anggota masyarakat (bangsa) secara bersama-sama (Supriono, Flassy \& Rais). Hal senada juga diungkapkan Arsyad,dkk. (2011) yang menyatakan bahwa modal sosial juga merupakan sebuah fenomena yang tumbuhdari bawah (bottom-up phenomenon), yang berasal dari sekumpulan individu yang membentukpola jalinan sosial (sosial network) yang didasarkan atas prinsip saling mempercayai (trust),resiprositas sosial, norma dalam berperilaku, serta aksi kolektif.

Cohen\&Prusak (2001) dalam Siregar (2011) menuliskan konsep awal modal sosial ditulis oleh Hanifan di tahun 1966, saat dia membicarakan tentang pusat komunitas yang terkait dengansekolah di wilayah pedesaan. Hanifan menggunakan istilah modal sosial untuk membicarakanfaktor substansi dalam kehidupan masyarakat yang antara lain berupa niat baik (good will), rasasimpati, perasaan persahabatan, dan hubungan sosial yang membentuk sebuah unit sosial.

Sedangkan dari sudut pandang ekonom, konsep modal sosial yang tertera dalam literature yang ditulis oleh Yustika (2010) dikenalkan oleh Pierre Bourdieu pada akhir tahun 1970-an dalamjudul tulisannya "Le Capital Sosial: Notes Provisoires" yang mendefinisikan modal sosial sebagaiagregat sumber daya aktual ataupun potensial yang diikat untuk mewujudkan jaringan yang awet(durable) sehingga melembagakan hubungan persahabatan (acquitance) yang salingmenguntungkan. Namun publikasi Bourdieu ini kurang mendapat perhatian karena ditulis dalambahasa Perancis. Konsep modal Sosial baru dikenal luas ketika James L. Coleman menulisnyadalam jurnal American Journal of Sociology yang berjudul "Sosial Capital in the Creation ofHuman Capital" di tahun 1988.

Coleman mendefinisikan modal sosial bukan entitas tunggal tetapi entitas majemuk yangmengandung dua elemen: (1) modal sosial mencakup beberapa aspek dari struktur sosial; dan (ii)modal sosial memfasilitasi tindakan tertentu dari pelaku (aktor) baik individu atau perusahaan didalam struktur tersebut (Coleman: 1988, dalam Yustika: 2010). Tiga bentuk modal sosial yangdisebutkan Coleman meliputi (1) struktur kewajiban, ekspektasi, dan kepercayaan; (2) jaringaninformasi; (3) norma dan sanksi yang efektif.

Namun yang patut diperhatikan adalah pengakuan atas modal sosial yang mulai dirasapenting hadir disamping dengan modal finansial (financial 
capital), maupun modal manusia(human capital). Siregar (2011) menyebutkan bahwa modal sosial ini merupakan salah satu bagiandari modal manusia disamping modal-modal lainnya seperti kompetensi, motivasi, sikap kerja, danbudaya/etos kerja.

Baker (2000), dalam Yustika (2010) mendefinisikan modal sosial sebagai sumber daya yangdiraih oleh pelakunya melalui struktur sosial yang spesifik, kemudian digunakan untuk memburu kepentingannya, dimana modal sosial tersebut diciptakan lewat perubahan-perubahan dalam hubungan antarpelakunya. Sedangkan Schiff (1999), Dalam Yustika (2010) mengartikan modalsosial sebagai seperangkat elemen struktur sosial yang mempengaruhi relasi antarmanusia dansekaligus sebagai input atau argumen bagi fungsi produksi dan manfaat (utility). Dan Burt (1997a),dalam Yustika (2010) memaknai modal sosial sebagai teman, kolega dan lebih umum kontaklewat siapa pun yang membuka peluang bagi pemanfaatan modal ekonomi dan manusia. Uphoff(1999), dalam Yustika (2010) menyatakan bahwa modal sosial dapat ditentukan sebagai akumulasi beragam tipe dari aspek sosial, psikologi, budaya, kelembagaan, dan aset yang tidak terlihat(intangible) yang mempengaruhi perilaku kerjasama. Dan, Putnam (1995) mengartikan modalsosial sebagai gambaran organisasi sosial, seperti jaringan norma dan kepercayaan sosial yang memfasilitasi koordinasi dan kerja sama yang saling menguntungkan (Yustika: 2010). Fukuyuma mendefinisikan modal sosial (sosial capital) sebagai norma informal yang dapat mendorong kerjasama antar anggota masyarakat (Fukuyama: 1995, dalam Siregar: 2011).

Dari banyaknya perbedaan batasan antar ahli tentang modal sosial, Syahyuti (2008) melihat beberapa ahli lebih menekankan pada pentingnya trust, sebagian lagi sosial network dan behavioral norms dalam modal sosial. Pengertian trust secara sederhana adalah "willingness totake a risk", yaitu, interaksi-interaksi yang didasari perasaan yakin (sense of confidence), bahwa orang lain akan memberikan respon sebagaimana diharapkan dan akan saling mendukung, atau setidaknya orang lain tak akan bermaksud menyakiti. Sehingga menimbulkan rasa aman (perceived safety) ketika berinteraksi dengan orang lain. Selain itu, Syahyuti juga menyatakan bahwa untuk mengembangkan modal sosial kata kuncinya adalah "waktu" (Syahyuti: 2008).Semakin lama seseorang terlibat dalam interaksi, maka modal sosial yang akan dimilikinya akanikut meningkat.

SedangkanTonkiss (dalam Syahyuti: 2008) mengingatkan bahwa modal sosial barulahbernilai ekonomis kalau dapat membantu individu atau kelompok, misalnya untuk mengakses sumber-sumber keuangan, mendapatkan informasi, menemukan pekerjaan, merintis usaha, dan meminimalkan biaya transaksi.

Inti telaah Modal Sosial terletak pada bagaimana kemampuan masyarakat dalam suatu entitas atau kelompok untuk bekerja sama membangun suatu jaringan untuk mencapai tujuan bersama. Kerjasama 
tersebut diwarnai oleh suatu pola interrelasi yang timbal balik dan saling menguntungkan, dan dibangun di atas kepercayaan yang ditopang oleh norma-norma dan nilai-nilai sosial yang positif dan kuat. Kekuatan tersebut akan maksimal jika didukung oleh semangat proaktif membuatjalinan hubungan di atas prinsip-prinsip yang disepakati.

Aspek-aspek modal sosial yang akan diungkap dalam pengabdian ini meliputi: (a) Partisipasi dalam suatu jaringan. Di mana modal sosial tidak dibangun hanya oleh satu individu, melainkan terletak pada kecenderungan yang tumbuh dalam suatu kelompokuntuk bersosialisasi sebagai bagian penting dari nilai-nilai yang melekat. Moal Sosial akan kuat tergantung pada kapasitas yang adadalam kelompok masyarakat untuk membangun sejumlah asosiasiberikut membangun jaringannya. (b)Resiprocity, di mana modal sosial senantiasa diwarnai oleh kecendrungan saling tukar kebaikan antar individu dalam suatu kelompok atau antar kelompokitu sendiri. Pola pertukaran ini bukanlah sesuatu yang dilakukan secara resiprokal, melainkan suatu kombinasi jangka pendek dan jangka panjang dalam nuansa altruism (semangat untuk membantu dan mementingkan kepentingan orang lain). (c) Rasa percaya diri (Trust) (mempercayai) adalah suatu bentuk keinginan untuk mengambil resiko dalam hubungan-hubungan sosialnya yang didasari oleh perasaan yakin bahwa yang lain akan melakukan sesuatu seperti yang diharapkan dan akan senantiasa bertindak dalam suatu pola tindakan yang saling mendukung, palingtidak yang lain tidak akan bertindak merugikan dari dan kelompoknya (Robert, 2002). Dalam pandangan Fukuyama (2002), trust adalah sikap saling mempercayai di masyarakat yang memungkinkan masyarakat tersebut saling bersatu dengan yang lain dan memberikan kontribusi pada peningkatan modal sosial. (d) Norma Sosial, yaitu sekumpulan aturan yang diharapkan dipatuhi dan diikuti oleh anggota kelompok arisan tertentu. Norma-normaini biasanya terinstusionalisasi dan mengandung sangsi sosial yang dapat mencegah individu berbuat sesuatu yang menyimpang dari kebiasaan. Atuaran kolektif tersebut biasanya tidak tertulis tapi dipahami oleh setiap anggota masyarakat dan menentukan polatingkah laku yang diharapkan dalam konteks hubungan sosial. (e) Nilai-nilai yaitu suatu yang dianggap benar dan penting oleh anggota masyarakat. Misalnya nilai harmoni, prestasi, kerja keras, kompetisidan lainnya merupakan contoh nilai yang sangat umum dikenal dalam masyarakat. Modal sosial yang kuat juga sangat ditentukan oleh konfigurasi yang tercipta pada suatu kelompok masyarakat. Jika suatu kelompok memberikan bobot tinggi pada nilai-nilai kompetisi, pencapaian, keterusterangan dan kejujuran, maka kelompok masyarakat tersebut cenderung jauh lebih cepat berkembang danmaju dibandingkan pada kelompok masyarakat yang senantiasa menghindari keterusterangan, kompetisi dan pencapaian. 
Selanjutnya adalah pemberdayaan masyarakat. Pemberdayaan masyarakat itu sendiri adalah suatu proses yang mengembangkan dan memperkuat kemampuan masyarakat untuk terusterlibat dalam proses pembangunan yang berlangsung secara dinamis sehingga masyarakat dapat menyelesaikan masalah yang dihadapi sertadapat mengambil keputusan secara bebas (independent) dan mandiri (Suyatno, 2003).

Senada dengan itu Hermawanti (2003) mengemukakan pemberdayaan masyarakat adalah mengembangkankondisi dan situasi sedemikian rupa hingga masyarakat memiliki dayadan kesempatan untuk mengembangkan kehidupannya tanpa adanyakesan bahwa perkembangan itu adalah hasil kekuatan eskternal,masyarakat harus dijadikan subyek bukan obyek. Sedangkan menurut Vidhyandika Moeljarto (2000) menyatakan bahwa pemberdayaan masyarakat banyak ditentukan oleh akses dan kontrol yang dimiliki subyek pembangunan itu pada berbagai sumber daya. Sumberdaya pembangunan yang utama adalah modal, termasuk didalamnya kepintaran, keterampilan, informasi dan teknologi di samping dana dantanah.

Perubahan paradigma yang terjadi kemudian, banyak negara belum juga berdampak positif bagi masyarakat. Upaya penanggulangan kemiskinan dan upaya membebaskan bangsa dari keterbelakangan senantiasa tidak menghasilkan sesuatu yang optimal. Hal ini erat kaitannya dengan tidak dimasukkannya modal sosial sebagai faktor penting dalam mempengaruhi efisiensi dan efektivitas kebijakan.

Kenyataan ini menumbuhkan kesadaran akan pentingnya dimensi kultural dan pendayagunaan peran lembaga-lembaga yang tumbuh dalam masyarakat untuk mempercepat dan mengoptimalkan proses-proses pembangunan. Fukuyama (2002) misalnya menyebutkan faktor kultural, khususnya modal sosial menempati posisi yang sangat penting sebagai faktor yang menentukan kualitas masyarakat.

Modal Sosial dan Pembangunan Manusia Putnam dalam Hasbullah (2006) menyatakan bahwa bangsa yang memiliki modal sosial tinggi cenderung lebih efisien dan efektif dalam menjalankan berbagai kebijakan untuk mensejahterakan dan memajukan kehidupan rakyatnya. Modal sosial dapat meningkatkan kesadaran individu tentang banyaknya peluang yang dapat dikembangkan untuk kepentingan masyarakat.

Modal Sosial dan Pembangunan Sosial Masyarakat yang memiliki modal sosial tinggi akan membuka kemungkinan menyelesaikan kompleksitas persoalan dengan lebih mudah. Dengan saling percaya, toleransi, dan kerjasama mereka dapat membangun jaringan baik di dalam kelompok masyarakatnya maupun dengan kelompok masyarakat lainnya.

Di samping itu, negara melalui sistem pemerintahan yang baik dapat mendorong menguatnya modal sosial yang mendukung berkembangnya kepercayaan, nilai-nilai, dan norma yang baik dengan menciptakan situasi yang kondusif dalam mempererat jaring-jaring sosial di dalam masyarakat 
dan merangsang tumbuhnya sikap proaktif masyarakat dalam pembangunan.

Terakhir, kegiatan arisan dapat dipandang sebagai gerakan sosial baru. Seturut dengan perkembagan kisah-kisah gerakan-gerakan sosial yang semakin beraneka ragam, tidak ada definisi tunggal mengenai konsep gerakan sosial sebagai suatu gejala sosial. Giddens 1993 dalam (Suharko, 2006:3) mendefinisikan gerakan sosial sebagai suatu upaya kolektif untuk mengejar suatu kepentingan bersama, atau tujuan bersama melalui tindakan kolektif (collective action) di luar lingkup lembagalembaga yang mapan.

\section{TUJUAN}

Tujuan atau target yang dicapai pada program KKN-Tematik ini, adalah: (1) Mendorong masyarakat untuk berpartisipasi dalam pembangunan. Sebab melalui pelatihan ini masyarakat dapat memperoleh wawasan dan keterampilan baru dalam mengelola sumber daya yang ada. (2) Membuka partisipasi dan keikutsertaan masyarakat secara langsung dalam pembagunan masyarakat desa. (3) Menumbuhkan nilai-nilai harmoni, prestasi, kerja keras, kompetisi dalam kehidupan bermasyarakat. Sehingga arisan dapat menjadi spirit atau kekuatan terwujudnya demokrasi ekonomi pada tataran akar rumput.

\section{METODE PENDIDIKAN DAN PELATIHAN}

Metode pendidikan dan pelatihan ini dilaksanakan guna menjawab masalah yang menjadi sasaran pengabdian ini: (1) Bagaimana meletakkan masyarakat sebagai motor pembangunan dengan modal yang mereka miliki (kepercayaan, kebersamaan, kepemimpinan, jaringan sosial). (2) Bagaimana menggali kembali potensi dan sumber daya yang ada di desa, baik yang belum maksimal maupun potensi yang belum tergali sama sekali. (3) Bagaimana melibatkan masyarakat secara langsung dalam perencanaan, pelaksanaan dan evaluasi terhadap pembanguan yang ada di sekitar mereka. (4) Bagaimana membangun interaksi sosial yang membawa mekanisme ekonomi pembangunan dalam masyarakat. (5)bagaimana membangun jaringan bersama antara masyarakat sebagai tempat berdiskusi, tukar pengalaman dan pengetahuan.

Guna menyederhanakan masalah di atas, maka gerakan sosial yang dibangun gunamengatasi kondisi sosial ekonomi masyarakat di Desa Sawerigadi adalah melalui gerakan arisan atau pokadulu dalam budaya masyarakat setempat. Gerakan ini merupakan kearifan lokal masyarakat Muna yang diwariskan secara turun temurun, namun karena pengelolaannya yang kurang maksimal sehingga budaya ini sudah mulai ditinggalkan. Oleh karena itu, melalui pelatihan ini budaya ini akan dihidupkan kembali atau direvitalisasi sehingga dapat menjawab persoalan kondisi sosial ekonomi masyarakat yang kian terpuruk dewasa ini. Padahal 
bila diaplikasikan dengan baik, arisan ini dapat menjadi gerakan sosial yang dapat menjadi perekat dan menjadi penunjang peningkatan pendapatan masyarakat.

Terakhir metode pendidikan dan pelatihan ini dimulai dari pendataan bakat dan hobi kelompok sasaran yang dijaring melalui angket, kemudian ditabulasi dan dikelompokkan berdasarkan keterampilan dan bakatnya masing-masing. Masyarakat dibina melalui metode ceramah, tanya-jawab untuk memberikan pengetahuan berupa pengetahuan dalam membangun ekonomi kerakyatan yang berbasis pemberdayaan. Selanjutnya pendampingan guna membina masyarakat berdasarkan masalah yang dihadapi secara bersama-sama, merencanakan kegiatan, pelaksanaan kegiatan, monitoring dan evaluasi oleh masyarakat sendiri yang didampingi oleh mahasiswa dan dosen pembimbing KKN.

\section{HASIL KEGIAT AN PENDIDIKAN DAN PELATIHAN}

\section{Pelaksanaan Kegiatan Pelatihan}

Kegiatan pelatihan ini, berlangsung pada tanggal 15 September 2015 di Balai Desa Sawerigadi. Dalam pertemuan ini, dosen pendamping lapangan (La Bilu) menjelaskan bahwa mahasiswa berada dilokasi KKN selama 45 hari terhitung mulai tanggal 6 Agustus hingga 18 September 2015. Program utamanya adalah pelatihan pemberdayaan masyarakat melalui arisan. Pilihan jenis produk ini adalah merupakan aspirasi masyarakat sementara mahasiswa KKN hanya membantu proses pembentukan kelompok arisan.

Pelatihan dibuka langsung oleh La Kuanto selaku Asisten I Pemerintah Kabupaten Muna Barat. la menjelaskan bahwa program ini akan dijadikan sebagai salah satu program unggulan karena manfaatnya dapat dirasakan masyarakat. Oleh karena itu, program ini kami akan dorong untuk meningkatkan pendapatan masyarakat.

Turut hadir dalam kegiatan ini adalah Ketua DPRD Kabupaten Muna Barat (La Ode Koso) bertindak selaku narasumber. Dalam amanatnya bahwa pembentukan kelompok ini sangat diapresiasi karena dapat membantu masyarakat dan pemerintah dalam mengatasi masalah kesenjangan ekonomi. Disamping itu, program ini benar-benar meletakan masyarakat sebagai pelaku pembangunan. la berharap sapi yang menjadi ternak peliharaan masyarakat benar-benar digembalakan dalam kawasan tertentu/melalui kandangsehingga tidak mengganggu atau menjadi hama tanaman masyarakat lainnya.

Dalam kesempatan ini juga, Asisten I melantik kelompok arisan sebagai wujud penguatan kelompok pokadulu. Pengukuhan ini, disaksikan oleh Ketua DPRD Muna Barat, Camat Barangka, Kepala Desa dan sejumlah tokoh lainnya. Terakhir adalah penyerahan sapi dari kelompok mahasiswa KKN kepada Masyarakat yang mendapat lotre arisan sebagai 
wujud keberhasilan program KKN-Tematik UHO di Desa Sawerigadi Kecamatan Barangka.

\section{Monitoring dan Evaluasi Program}

Monitoring dan evaluasi dapat dilakukan satu paket.Monitoring dilakukan selama empat kali pertemuan. Pertama, monitoring pada saat penempatan mahasiswa KKN, kedua monitoring dilakukan pada minggu ke 2 untuk melihat apakah dalam minggu pertama mahasiswa berhasil membentuk kelompok masyarakat, ketiga,monitoring dilaksanakan pada minggu ke 3 guna melihat bagaimana partisipasi masyarakat dalam kelompok dan terakhir pada saat penarikan mahasiswa KKN guna melakukan evaluasi secara menyeluruh.

Hasil evaluasi menunjukkan bahwa hasil pelatihan menunjukkan suatu keberhasilan yang cukup menggembirakan hal ini tampak seperti pada uraian tabel dibawah ini.

Tabel 4.2.

Evaluasi Kemampuan Penguasaan Materi Selama Proses Pelatihan

\begin{tabular}{|c|c|c|c|c|}
\hline No & Kategori & Rentang Nilai & Jumlah & $\begin{array}{c}\text { Persentase } \\
(\%)\end{array}$ \\
\hline 1 & Baik sekali & $86-100$ & 76 & 61 \\
\hline 2 & Baik & $75-85$ & 48 & 39 \\
\hline 3 & Kurang Baik & $65-74$ & - & - \\
\hline 4 & Tidak Baik & Kurang dari 65 & 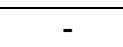 & - \\
\hline \multicolumn{3}{|c|}{ Jumlah } & 124 & $100 \%$ \\
\hline
\end{tabular}

Sumber: Angket diolah

Data tabel di atas, tampak bahwa keberhasilan pelatihan sangat tampak di mana dari 124 peserta pelatihan $61 \%$ menunjukkan kategori baik sekali sebagai tanda sangat memahami dan menerima program pelatihan ini. Demikian pula $39 \%$ menyatakan bahwa pelatihan ini baik, karena manfaatnya langsung dirasakan oleh masyarakat.

\section{KESIMPULAN DAN REKOMENDASI}

Berdasarkan uraian pembahasan di atas, pelaksanaan kegiatan KKN - Tematik di Desa Sawerigadi dinyatakan sukses dilaksanakan. Hal ini dapat ditunjukan dengan indikator keberhasilan evaluasi pelaksanaan pelatihan yakni 76 orang atau (61\%) menunjukkan rentang nilai 86-100 dengan kategori baik sekali, $39 \%$ dengan kategori baik. Keberhasilan ini juga dapat dilihat dari keberlangsung program ini, dimana arisan telah dilakukan 1 putaran dan diikuti oleh semua anggota.

Program-program yang diintroduksikan kepada kelompok sasaran ini menghasilkan suatu rekomendasi keberlanjutan program untuk pemerintah daerah tingkat kecamatan, kabupaten dan provinsi. Keberlanjutan program juga direkomendasikan untuk LPPM UHO bagi pelaksanaan KKN-Tematik periode berikutnya. 


\section{DAFTAR PUSTAKA}

Arsyad, Lincolin, dkk. 2011. Strategi Pembangunan Perdesaan Berbasis Lokal, Yogyakarta: STIM/YKPN Yogyakarta.

Bambang, Rustanto, 2007. Penguatan Keluarga Miskin Melalui Pengembangan Modal Sosial, dalam jurnal Pusat Penelitian dan Pengembangan Kesejahteraan Sosial Kementrian Sosial Republik Indonesia Vol. 12 No. 03 tahun 2007

Coleman, J. 1988. Sosial Capital in the Creation of Human Capital. American Journalof Sociology 94 (Supplement): S95-S120.

Fukuyama,F. 2000. Social Capital. in Culture Matters: How Values Shape . Progress (Edited by L.E. Harrison and S.P.Hutington). Basic Books. New York.

Giddens, Anthony, (1993). Sosiology, Oxford: Polity Press.Inayah, 2012. Peranan Modal Sosial dalam Pembangunan, Jurnal Pengembangan Humaniora. Vol 12(1) 2012.

Khusnul Ashar, 2009. Kajian Pendekatan Lembaga Keuangan Arisan Plus (Lka+) Sebagai Upaya Pengentasan Kemiskinan di Kawasan Pariwisata Batu, dalam jurnal Ilmu-llmu Sosial (Sosial Science) Volume 21 Nomor 1 Pebruari 2009,

Moeljarto Tjokrowinoto, 2002. Pembangunan Dilema dan Tantangan, Yogyakarta: Pustaka Pelajar.

Mujiyadi, 2012. Pemberdayaan Masyarakat Miskin Pinggiran Kota (Studi Pekerjaan Sosial Tentang Petani Penggarap di Lahan Sementara, dalam jurnal Sosiokonsepsia Vol. 17. No. 02 Tahun 2012.

Oman Sukmana, 2005. Strategi Pemberdayaan Masyarakat Miskin Melalui Pengembangan Institusi dan Modal Sosial Lokal (Studi Pada Masyarakat Miskin Pedesaan di Wilayah Kecamatan Pujon Kabupaten Malang, Jurnal Humanity, Volume 1 Nomor 1 September 2005.

Pelly, Usman dan Menanti, Asih 1994. Teori-Teori Sosial Budaya, Proyek Pembinaan dan Peningkatan Mutu Tenaga Kependidikan, Jakarta: Dikti, dalam Jurnal Pendidikan Sosiologi dan Humaniora Vol. 1. No. 1. April 2010.

Primadona, 2012. Penguatan Modal Sosial Untuk Pemberdayaan Masyarakat Dalam Pembangunan Pedesaan (Studi Kelompok Tani Kecamatan Rambatan), dalam jurnal Polibisnis, Volume 4 No. 1 April 2012.

Putman, Rober, 1993, 2000. The Prosperous Community-sosial Capital and Public Life, American.

Robert Chambers, 1996.Participatory Rural Appraisal (Memahami Desa SecaraPartisipatifj, Terjemahan Y. Sukoco, Yogyakarta: Kanisius.

Siregar, 2011. Modal Sosial Para Pedagang Kaki Lima Etnis Jawa Studi di Daerah Nagoya Kota Batam. Jurnal Fisip UMRAH. Vol 1(1): 93-106. 
Suharko, 2006.Gerakan Sosial Baru di Indonesia: Repertoar Gerakan Petani, Jurnal IImu Sosial dan IImu Politik UGM Volume 10 Nomor 1, Juli 2006, ISSN 1410-4946.

Suyatno, Hempri dan Suparjan, 2003.Pengembangan Masyarakat: DariPembangunan Sampai Pemberdayaan, Yogyakarta: Aditya Media.

Suseno, F. Magnis, 2010. Pemikiran Karl Marx Dari Sosialis Utopis ke Perselisihan Revionisme, Jakarta; Gramedia Persada.

Syahyuti, 2008. Peran Modal Sosial (Sosial Capital) Dalam perdagangan Hasil Pertanian. (The Role Sosial Capital In Agricultural Trade), Jurnal Forum Penelitian Agro Ekonomi. Vol26(1): 2008: 32-43.

Tri Panadji, 2006. Penguatan Modal Sosial Untuk Pemberdayaan Masyarakat Dalam Pembangunan Pedesaan (Kelompok Tani Kecamatan Rambatan), dalam Jurnal Agro Ekonomi Volume 2 Oktober 2006.

Yustika, Ahmad Erani, 2010. Ekonomi Kelembagaan, Definisi, Teori dan Strategi, Malang:Banyumedia Publishing. 